\title{
Rape, Intoxication and the Concept of Consent
}

\author{
Porbjörg Sveinsdóttir, assistant prosecutor at Iceland's District \\ Prosecutor's Office
}

\begin{abstract}
In this article the applicability of the concept of consent is examined in rape cases where the complainant is voluntarily intoxicated. Consent has been at the core of the offence of rape in England for quite some time and the applicability of the concept in such cases in England is examined. The article argues that the concept of consent has not been adequately able to address cases of voluntary intoxication in England, demonstrating that the concept of consent is particularly problematic when it comes to such cases, both due to its ambiguous meaning and its subjective nature. It is furthermore argued that a coercion-based definition of rape, which the Nordic countries have all until recently adhered to, may provide for a more workable yardstick in cases of voluntary intoxication. The recent introduction of a consent-based definition of rape in Swedish and Icelandic law is examined along with how it applies to cases of voluntary intoxication. The article concludes that although both Sweden and Iceland have recently amended their rape laws as to include consent-based definitions of rape, both countries have in effect adhered to a coercion-based model when it comes to cases of voluntary intoxication, relying on yardsticks focusing on the physical.
\end{abstract}

\section{Keywords}

Rape, Consent, Intoxication, England, Sweden, Iceland

\section{Introduction}

While the introduction of the concept of consent in rape laws in the Nordic countries is a very recent construct, the concept of consent has been at the core of the offence of rape in certain other legal jurisdictions for quite some time. This is the case for England; rape in English law is defined as intentional penetration of the vagina, anus or mouth of another person with the perpetrators penis without consent and without reasonably belief of consent (Sexual Offences Act 2003, s 1). In this article I examine the applicability of the concept of consent in cases of voluntary complainant intoxication. Intoxication is a common feature in rape cases; a considerable number of both defendants and complainants have taken drink prior 
to the offence (Cowan, 2008, p. 904). I examine how English law addresses rape when the complainant is intoxicated; in particular, how the general definition of consent included in the Sexual Offences Act 2003 (hereafter referred to as 'SOA 2003') has been applied to cases where complainants have been voluntarily intoxicated during the act (hereafter referred to as 'voluntary intoxication'). My argument is that the general definition of consent has not been adequately able to address cases of voluntary intoxication, at least, not how it has been interpreted by the English courts. I furthermore argue that the concept of consent is particularly problematic when it comes to voluntary intoxication, both due to its ambiguous meaning and its subjective nature. A coercion-based model may have an important advantage over a consent-based model in cases of voluntary intoxication whereas its primary focus is not on the complainant's mental capabilities at a certain point of drunkenness but rather on how the complainant's physical capabilities are impaired. My conclusion is that if consent is to be relied on in such cases the law should be amended to provide a clearer legislative guidance as to when a complainant's intoxication negates consent, focusing on the physical effects of intoxication on the complainant. I then move on to examine the legal position of the Nordic countries when it comes to cases of voluntary intoxication with special regard to recent legal developements in Sweden and Iceland. I study how these countries have introduced consent-based definitions of rape in connection to voluntary intoxication and compare this to my previous findings regarding English law. I conclude that although both Sweden and Iceland have recently implemented a consent-based model both countries have in effect adhered to a coercionbased model when it comes to cases of voluntary intoxication, thus adhering to yardsticks focusing on the physical.

\section{The Definition of Consent in English Law - SOA 2003}

The aim of the English government to clarify the law on rape by setting out a clear and unambiguous statutory definition of consent is clear from the Home Office Report Setting the Boundaries that became the base of SOA 2003. Setting the Boundaries argued that an ambiguous and broad concept of consent risks being interpreted in an inconsistent manner from case to case and that the law should be reformed to include a clear concept of consent based on a free agreement between two equals, who both have the capacity to make that choice, rather than one submitting to the will of another (Home Office, 2000, paras 2.2.3 and 2.4.2; Sjölin, 2015, pp. 22, 34; $R v$ Olugboja [1982] QB 320, para 332). The report proposed that this should be done through a two-tiered approach, including a statutory definition of consent and a list of non-exhaustive list of circumstances when consent 
or free agreement is not present (Home Office, 2000, Recommendation 5 and para 2.10.6). The Report envisaged the list as a starting point but considered that the courts would develop the law further by applying the general definition of consent to other circumstances than those captured by the list (Home Office, 2000, para 2.10.7). The structure of the SOA 2003 is largely based on the proposals, albeit with some changes. The act includes a general consent based definition of rape and an exhaustive list of presumptions that describe circumstances where there is an assumed lack of consent. In proving rape the prosecution can thus either prove that one of the irrebuttable ${ }^{1}$ or rebuttable ${ }^{2}$ presumptions is present or, if none of these circumstances are present, to prove that there was nonetheless a lack of consent, thus basing the case on the general definition of consent (SOA 2003, s 74).

While two of the (rebuttable) presumptions can be applicable in cases where the complainant is intoxicated they are only applicable to a limited number of cases, i.e. where the complainant is unconscious (SOA 2003, s. 75(2)(d)) or where another person had administered a substance to the complainant, capable of causing the complainant to be overpowered or stupefied (SOA 2003, s. 75(2)(f)). The focus here will not be on these presumptions but rather on the general definition of consent, which is relied on in cases when the complainant is voluntarily intoxicated but not to the point of having lost consciousness. The general definition of consent in SOA 2003 is as follows: 'A person consents if he agrees by choice, and has the freedom and capacity to make that choice' (SOA 2003, s. 74). It is thus put in the hands of the courts to direct juries in interpreting and applying the concepts of 'choice', 'freedom' and 'capacity', and in the process, give jury directions that challenge what can be viewed as 'stereotypical thinking' (Temkin and Ashworth, 2003, p. 333). The following chapter will examine how the general definition of consent has been applied in cases of voluntary intoxication in England.

1. The circumstances that lead to an irrebuttable presumption of non-consent are circumstances where the defendant has used deception, either as to the nature of purpose of the sexual act (s. 76(2)(a)) or by impersonating someone personally known to the complainant (s. 76(2)(b)).

2. The circumstances that presume that consent was not given, but where this presumption is rebuttable, involve violence or the threat of immediate violence against the complainant (s. 75(2)(a)) or another person (s. 75(2)(b)), circumstances where the complainant is unlawfully detained (s. 75(2)(c)), asleep or unconscious (s. 75(2)(d)), unable to communicate consent due to physical disability (s. 75(2)(e)) or is involuntarily intoxicated (s. 75(2)(f)). 


\section{The Application of the SOA 2003 in Cases of Voluntary Intoxication}

$R v$ Bree ( $R v$ Bree [2007] EWCA Crim 804) is considered a landmark ruling regarding the interpretation of SOA 2003 in cases of voluntary intoxication. In Bree the defendant was convicted but the judgement was squashed on appeal whereas the jury was considered to have lacked proper direction as to the impact of the complainant's intoxication on her capacity to consent and whether they could also take that in account in deciding whether she consented (R v Bree [2007] EWCA Crim 804, para 39). The complainant had shortly before the sexual act thrown up repeatedly and had been 'taken care of' by the defendant. According to the complainant herself, she had lost consciousness, while the defendant held that the complainant had been conscious and had consented by reacting positively to his advances and removed her clothes ( $R v$ Bree [2007] EWCA Crim 804, paras 6-9, 13-18). The prosecution initially based its case on the complainant's lack of capacity to consent due to her being unconscious but then revised its case and stated that the complainant had been conscious and thus retained the capacity to consent but did not consent whereas her ability to resist the defendant was hampered $(R v$ Bree [2007] EWCA Crim 804, para 20). The judge's words in $R v$ Dougal, $^{3}$ another landmark case of voluntary intoxication (where the jury was instructed by the trial judge to find the defendant not guilty, whereas the complainant claimed that she could not remember whether she consented or not, due to intoxication), that 'drunken consent is still consent' were considered by the Appeals Court in Bree to accurately describe the legal position although lacking delicacy $(R v$ Bree [2007] EWCA Crim 804, paras 30-32).

While the Appeals Court in $R$. v. Bree acknowledged that the capacity to consent could disappear before the complainant became unconscious $(R v$ Bree [2007] EWCA Crim 804, para 34) it has been criticised for offering limited guidance as to what yardstick should be applied in determining when intoxication reaches the level of making a person incapable og consenting to sexual acts (Elvin, 2008, pp. 523-525) and furthermore not applying the principle that it established but rather, in line with Dougal, takes factual consent as legal consent (Wallerstein, 2009, p. 321). This criticism has some merit to it; the Appeals Court in Bree distinguished the 'critical aspect of the case' as the issue whether the complainant might have behaved differently when drunk and thus behaved as the

3. In $R v$ Dougal the jury was instructed by the trial judge to find the defendant not guilty, whereas the complainant claimed that she could not remember whether she consented or not, due to intoxication. 
defendant held ( $R v$ Bree [2007] EWCA Crim 804, para 42) (i.e. leading him on), but did not address the issue directly whether the complainant's intoxication might have rendered her incapable to consent. In $R v$ Hysa (R v Hysa [2007] EWCA Crim 2056), the Appeals Court, however, applied the principle established in Bree that the capacity to consent could evaporate due to intoxication while the complainant was still conscious (Wallerstein, 2009, p. 322; Simpson, 2016, p. 113). ${ }^{4}$ However, like in Bree, little guidance was offered as to what yardstick should be applied in determining when intoxication reaches the level of making a person incapable of consenting to sexual acts (Elvin, 2008, pp. 523527).

So what guidance can this case law offer when it comes to determining when a complainant is not capable of consenting due to intoxication? There seems to be a widespread consensus that the SOA 2003 has failed to achieve the clarity that the Government aimed for in cases of voluntary intoxication, both to a lack of legal clarity (Elvin, 2008, pp. 535) and adequate jury direction (Cowan, 2008, p. 921; Temkin and Ashworth, 2003; Simpson, 2016, p. 110). The law set out in Bree, Dougal and Hiya has furthermore been criticised for being too restrictive, in that even if the complainant is extremely intoxicated factual consent is presumed to be legal consent and because an extremely high level of intoxication is required before the issue of capacity to consent is put into question (Cowan, 2008, pp. 914-915; Wallerstein, 2009, p. 322-323). The courts seem to have adhered to the position that the capacity to consent is not compromised unless the complainant is extremely intoxicated; in $R v$ Kamki ( $R v$ Kamki [2013] EWCA Crim 2335) the judge's directions relating to the capacity to consent focused on whether the complainant had lost a certain degree of consciousness, with the judge directing the jury that "In a state of dim and drunken awareness, a person may not be in a condition to make choices". The judgement is referred to in the The Crown Court Compendium (Judicial College, 2019) as guidance to judges when summing up cases in the Crown Court in cases of voluntary intoxication (Judicial College, 2019, p. 20-21). A certain level of unconsciousness has thus become the yardstick that is applied in cases of voluntary intoxication, requiring a very high level of intoxication before questioning the capacity to consent. Consciousness is thus considered to translate into a complainant being capable to

4. It has since been established that the fact that the complainant does not remember whether she consented or not due to memory loss, is an independent issue from the capacity to consent, $R$ v Seedy Tambedou [2014] EWCA Crim 954, para 16. 
consent, even in cases where complainants have held that they were so drunk that they vomited, cannot remember the events or remember not wanting sex and feel that they were unable to resist physically because of intoxication (Cowan, 2008, pp. 914-915).

The question arises whether there is need for a legal clarification that furthermore moves from the narrow judicial interpretation of capacity to consent in cases of voluntary intoxication. While some have advocated for legislative amendments, others have considered that detailed jury directions would be sufficient to clarify the legal situation (Home Office, 2000, Recommendation 7, para 2.11; Cowan, 2008, p. 921; Sjölin, 2015, p. 30; Wallerstein, 2009, p. 343-344). Andrew Ashworth considers that in cases of voluntary intoxication judges should direct juries to assess capacity in terms of the complainants' awareness and understanding of the situation and ability to make the choice (Ashworth, 2007, p. 903). The Crown Court Compendium reflects this to some extent; in applying s 74 of SOA 2003, the courts should look to whether the complainant's understanding and knowledge is so limited that she cannot decide whether to agree to the act (Judicial College, p. 20-21). The assessment of the complainant's capacity to consent, however, continues to be left to the common sense of juries. This has been held to lead to inconsistencies in the application of the law and to be effected by gender stereotypes (Cowan, 2008, p. 911-912; Home Office, 2000, para 2.2.3; Simpson, 2016, p. 112-114; Finch and Munro, 2007, p. 599). It follows that while the general definition of consent in the SOA 2003 might allow for a more drastic interpretation (Wallerstein, 2009, p. 343-344), legislative changes seem to be inevitable if the capacity to consent is to be approached in a different manner than the English courts have done. The issue that remains is the question whether the law can provide further guidance when assessing the capacity to consent. In Bree, Sir Igor Judge commented that the issue of capacity to consent in cases of voluntary intoxication is simply an area 'inapt from detailed legislative structure' whereas the law cannot through a 'grid system' determine that a certain level of alcohol consumption leaves a person incapable to consent (R v Bree [2007] EWCA Crim 804, paras 34-36). This sentiment - that the law simply cannot provide a test applicable to these circumstances - seems to be shared by many (Cowan, 2008, p. 911; Ashworth, 2007, p. 903; Scottish Law Commission, 2007, para 2.63.). While I do not suggest that this is a simple thing to address, Sir Igor Judge's reasoning seems to be largely based on a very narrow view on how the law can address cases of voluntary intoxication. It seems that there are various other ways to address the issue of rape where the complainant is severely intoxicated than introducing rules based on the number of alcohol units that she has consumed. The 
way that the law may address these circumstances will be the subject of the following chapters.

\section{Clarifying the Meaning of Consent in Cases of Voluntary Intoxication}

How can the law assess whether a severely intoxicated person was to make a choice at a certain point? Shlomit Wallerstein argues that once a woman has reached the point of intoxication that she acts out of character and can no longer say 'no', she has become incapable of a free choice to say 'yes' (Wallerstein, 2009 , p. 333). While it seems logical that if a person cannot say 'no' she can not choose, assessing a person's inability of saying 'no' is not an easy task. While Wallerstein refers to a woman acting out of character in this context it seems that the yardstick of altered behaviour is highly problematic. Some people may act quite out of character after consuming alcohol without being severely intoxicated. Furthermore, there seems to be a widespread consensus that a distinction must be made between intoxication resulting in a lack of capacity to consent on one hand and intoxication that alters a person's choices on the other, due to the disinhibiting effect of alcohol. ${ }^{5}$ Drawing the line between these two scenarios seems to be at the heart of the issue of determining when a person loses her capacity to consent due to intoxication. So where does the line lie between a 'bad' choice - including a choice that a person may never have made sober - and the incapacity to make a choice?

Sharon Cowan argues that the law should be amended as to consider consent in a state of 'extreme drunkenness' as non-consent, or at least that consent in such circumstances should be presumed not to be present (Cowan, 2008, p. 921). Cowan proposes that the inability to speak or move, vomiting, periods of unconsciousness and memory loss should all suggest that there is a lack of capacity to consent, unless the defendant shows that the complainant did have the capability to consent and did so (Cowan, 2008, p. 917). What Cowan is in fact suggesting, is that the physical effects of extreme drunkenness be used as a yardstick to assess its subjective effects, i.e. on the complainant's capacity to consent. This brings us to the fundamental issue of evidence. The clearest evidence of a state of extreme drunkenness tends to demonstrate its physical impact. Evidence of the complain-

5. This has been the position of the Appeals Court as has been the subject of the preceding chapter. This position is also reflected in the 2016 Consultation Paper Convicting Rapists and Protecting Victims - Justice for Victims of Rape, that recommended that the legal definition of consent be clarified. Office for Criminal Justice Reform, 2016, p. 14. 
ant's memory loss, difficulties of walking, being sick and reaching a level of helplessness seems to be prevalent in cases of voluntary intoxication. On the other hand evidence as to the complainant's level of understanding and knowledge (to use Ashworth's guidance) at the moment of sexual intercourse is generally limited - both due to the fact that evidence of the physical is generally easier to come by than evidence of the subjective, and also because in cases of rape evidence of the complainant's mental capabilities at the moment of the sexual act are particularly difficult to come by due to the nature of the offence; generally the only witness to the complainant's mental capabilities at that moment is the defendant. The subjective nature of the concept of consent, therefore, seems to be particularly problematic in cases of voluntary intoxication.

\section{The Subjective Nature of Consent and Evidence of Voluntary Intoxication}

Legal systems and commentators alike differ in whether consent is or should be defined as purely subjective or whether its expression should be objectively formed (Ferzan and Westen, 2017, pp. 777-778). However, while consent is primarily a subjective concept, rape trials often revolve around analysing the behaviour and bodily responses of the complainant (Cowan, 2008, p. 903). This connects to the aforementioned evidential difficulties when assessing a subjective concept; in the absence of evidence of the mental capabilities of the complainant, evidence of the physical is used to try to assess the subjective. The role of consent in cases of rape is, in fact, widely considered to result in severe scrutiny of the complainants' actions and that this scrutiny may accentuate stereotypical views of jurors (Finch and Munro, 2007, p. 606; Tadros, 2006, pp. 516-517). It has been held that a consent-based offence of rape may thus be particularly sensitive to the prejudices of trial participants and furthermore, due to its ambiguous nature, susceptible to manipulation by the defence (Tadros, 2006, pp. 516-517). With regard to the evidence of the public's perception of intoxicated rape victims (Cowan, 2008, pp. 911-912; Simpson, 2016, pp. 112-114; Finch and Munro, 2007, p. 599), these arguments against a consent-based model seem to carry particular weight when it comes to cases of voluntary intoxication (Munro, 2011, p. 20).

In comparison, rape laws based on coercion or the use of force in a broad sense have been considered to have the advantage of focusing on the defendant's actions, rather than on the consent of the complainant and thus sparing the complainant to be 'put on trial' (Ferzan and Westen, 2017, pp. 773). The coercionbased model, furthermore, has an important advantage over a consent-based model in cases of intoxication; its primary focus is not on the complainant's mental capabilities at a certain point of drunkenness. Rather, the focus is on how the 
complainant's physical capabilities are impaired. A coercion-based offence may, therefore, offer clearer legislative guidance as to the effects of voluntary intoxication in cases of rape than the consent-based model, especially when the latter type of offence offers no guidance as to what can be deduced about the complainant's capacity to consent from the evidence of the physical effects of intoxication. An examination of the law on rape in the Nordic countries, who have all up until recently adhered to a coercion-based model, might provide an illustrative example of this.

\section{The Legal Position of the Nordic Countries - Cases of Voluntary Intoxication and Consent}

In Norway (s 291(b) of the Norwegian penal code (Lov om straff LOV-2005-0520-28), Denmark (s 216(1)(2) of the Danish penal code (Straffeloven no. 1156/2018) and Iceland (s 194(2) of the Icelandic penal code (Almenn hegningarlög no. 19/1940)) the provisions that have generally been applied in cases of voluntary intoxication stipulates that rape is committed when a person cannot resist the sexual advances of another (or understand its meaning), while the Finnish (ch 20 s 1(2) of the Finnish penal code (Rikoslaki no. 39/1889)) ${ }^{6}$ and Swedish ${ }^{7}$ provisions have both up until recently relied on an offence that stipulates that engaging in a sexual act with a person by exploiting her vulnerable or helpless state is rape. It may be argued that not being able to resist something or being vulnerable or helpless are concepts that can be manipulated or interpreted in a narrow manner just like the concept of consent. However, the fact that these concepts focus on the physical capabilities of the complainant rather than their cognitive capabilities might make their application easier in cases of voluntary intoxication. Sweden and Iceland have, at least, decided against relying on a general definition of consent in cases of voluntary intoxication although both countries have recently implemented a consent-based model of rape. The rationale behind this approach will be the subject of this chapter.

In 2018 Sweden implemented a consent-based definition of rape (ch $6 \mathrm{~s} 1$ of the Swedish penal code (Brottsbalken no. 1962:700). It should, however, be noted that the final legal amendments did not include the concept of consent, but ra-

6. The Finnish penal provision also refers to the person being unable to defend himself or herself og express his or her will.

7. Before the 2018 changes that will be the subject of this chapter the applicable offence was ch 6 s 3 of the Swedish penal code (Brottsbalken no. 1962:700). 
ther the concept of voluntariness ("frivillighet") the reason for this being that the concept of consent already has a place in the Swedish penal code as a defence, absolving the defendant of criminal liability (Regeringens proposition, 2017, p. 30). In spite of this, the preparatory documents refer to the law as being based on consent and it is generally referred to as the consent-law ("samtyckeslagen") (Vestergaard 2019, p. 279; Regeringens proposition, 2017, p. 22; Statens offentliga utredningar, 2016, p. 125). Before the law was passed in 2018 there were widespread concerns in Sweden that due to the ambiguous meaning of consent, people's sexual autonomy would be afforded less protection if the current offence of rape in Swedish law would be replaced by a consent-based offence (Statens offentliga utredningar, 2016, p. 180). To meet these concerns, the Committee appointed by the Swedish Parliament, that proposed introducing a consent-based model of rape into Swedish law, suggested that the consent-based model should include irrebuttable legal presumptions to better capture cases of complainant intoxication (Statens offentliga utredningar, 2016, pp. 201-202). The amendments to the Swedish criminal code that were passed in 2018 include legal presumptions that stipulate that a person can never be considered to be participating voluntarily in sexual intercourse or in a comparable sexual act when the defendant has improperly taken advantage of a person who is in a particularly vulnerable situation inter alia due to intoxication or other drug influence (ch $6 \mathrm{~s} 1$ of Brottsbalken no. 1962:700). The Swedish coercion-based offence applicable to cases of intoxication is thus retained (albeit with some changes) but placed within the context of consent (voluntariness), so as to ensure that the protection of intoxicated complainants would not diminish with the introduction of a consent-based offence of rape (Statens offentliga utredningar, 2016, p. 137; Burman, 2011, p. 209).

Iceland, on the other hand, opted for a mixed model when amending the Icelandic penal code's rape provision in 2018 (Article 194 of the Icelandic penal code (Almenn hegningarlög nr. 19/1940), by both adopting a consent-based offence of rape and also retaining the former offence of rape that is not based on consent but grounded on the yardstick of the complainant being unable to resist the defendant. The reasoning behind retaining this coercion-based offence of rape is, according to the preparatory documents accompanying the proposal to introduce a consent-based type of offence in Iceland, simply that in instances where the victim cannot resist or comprehend the sexual act, consent does not have any 'significance' because of the victim's state (Alpingi, 2017-2018, p. 9). Albeit this limited argumentation, it is clear that the position of the Icelandic legislator is that the yardstick of being unable to resist sexual advances is more suitable in cases of voluntary intoxication than the concept of consent. This offence has been applied 
in cases of extreme intoxication comparable to Bree, i.e. where the complainant has been intoxicated to the point of being sick and has been 'taken care of' by the defendant who has then had intercourse with the complainant (Iceland's Supreme Court Judgements no. 644/2015 and 252/2016). The physical effects of intoxication, i.e. the complainant's ability to physically resist the defendant, seem to provide for a more 'workable' yardstick than consent in these circumstances. The fact that the prosecution in Bree tried to use this criterion, claiming that due to the complainant's intoxication her ability to resist the defendant was hampered $(R v$ Bree [2007] EWCA Crim 804), seems to provide an illustrative example of this. Gardner might be regarded as another example of a case where a focus on the complainant's physical abilities would have provided clearer guidance than the concept of consent; it seems clear that under the circumstances the complainant, who was vomiting and unable to answer, was not in a position to resist the advances of the defendant ( $R v$ Gardner [2005] EWCA Crim 1399).

Although Sweden and Iceland are the only Nordic countries that have amended their rape laws as to include consent-based definitions of rape at the time of writing the other Nordic countries have also considered adapting their rape laws to include a consent-based provision. In Finland and Norway, the issue of the introduction of consent-based legislation is still being debated (Vestergaard 2019, p. 278; Justis- og beredskapsdepartementet, 2019, p. 50) while Denmark is in the process of implementing a consent-based model of rape. In line with the Swedish legal amendments that have been the subject of this chapter the legal amendments proposed by the majority of the Danish Penal Committee (Straffelovrådet) are based on the concept of voluntariness rather than consent (Justitsministeriet 2020, p. 174). The Danish Penal Committee, however, states that the two concepts are more or less identical ("sammenfaldende") (Justitsministeriet 2020, p. 14). The proposal put forward by the majority of the Committee is largely in line with the Swedish legal amendments, with the legal proposal placing Denmark's coercionbased offence currently applicable in cases of intoxication within the context of consent (Justitsministeriet 2020, p. 174). The applicability of a consent-based definition of rape in cases of voluntary intoxication thus continues to be a highly relevant topic in the Nordic countries.

\section{The Approach to Consent in England, Sweden and Iceland in Cases of Voluntary Intoxication - Providing Legislative Guidance as to when Intoxication Negates the Capacity to Consent}

My previous conclusion is that the concept of consent alone is not a viable tool to assess cases of complainant intoxication, as I have argued the legal position in 
England has demonstrated. The question thus arises whether the consent-based model should be departed from or whether it should be amended to counteract the difficulties of proving an intoxicated person's mental capability at a certain moment in time? While Sweden has attempted to address the shortcomings of the concept of consent through irrebuttable legal presumptions in an attempt to provide clearer legislative guidance as to when a complainant's intoxication negates her consent, Iceland seems to have rejected the concept of consent as the base of the offence of rape in cases of complainant intoxication. It could be argued that in practice the position of these two countries might in effect by quite similar; while Sweden places cases of complainant intoxication within the umbrella of consent it adheres to the yardstick previously applicable in such cases - just like Iceland. The interpretation of these provisions are, of course, dependent on the courts of these two countries and at the time of writing the effect of the introduction of consent-based rape provisions on rape cases in Sweden and Iceland is still somewhat unclear (Justitsministeriet, 2020, pp. 81, 102; Vestergaard, 2019, p. 285, Brå, 2020) ${ }^{8}$ While the legal effect of these two different approaches remain to be seen, the question might be asked whether placing cases of voluntary intoxication under the umbrella of consent or not makes any difference in terms of labelling.

While some have argued for a departure from a consent-based offence of rape (Tadros, 2006; Munro, 2011, p. 21), the general view seems to be that consent best captures the wrong committed by rape, i.e. the violation of a person's sexual autonomy (Home Office, 2000, para 2.7.2). The Icelandic approach might give the impression that there are two distinct wrongs committed by creating one consent-based offence and one coercion-based offence of rape, with the latter offence based on a misrepresentation of the nature of the wrong (Munro, 2011, p. 26). In

8. According to initial reports the introduction of a consent-based rape provision has not necessarily had much effect on rape convictions in general in Sweden and Iceland (Justitsministeriet, 2020, pp. 81, 102; Vestergaard, 2019, p. 285). However, according to a report published by the Swedish government agency Brå in June 2020, there has been a signficant increase in prosecutions and convictions of rape cases in Sweden in general since the legal amendments came into action (Brå, 2020, p. 82). Although it is too early to draw any final conclusions based on this increase (Brå, 2020, p. 82), a number of prosecutors in Sweden seem to be of the opinion that the legal amendments have had an impact on cases of complainant intoxication whereas they have allowed judges more flexibility in interpreting the meaning of an especially vulnerable situation, allowing them to take into account the circumstances as a whole, even if the complainant was not necessarily drunk to the point of passing out (although judges in Sweden don't necessarily seem to agree with this assumption) (Brå, 2020, pp. 72-73). 
line with this, a consent-based offence could be viewed as a better alternative to navigate the issue of consent in cases of voluntary intoxication. If consent is to be relied on the law should, however, be amended to provide a clearer legislative guidance as to when a complainant's intoxication negates her consent than England has done, preferably focusing on the physical effects of intoxication on the complainant. The Swedish position of introducing an irrebuttable legal presumption based on a defendant improperly using a person who is in a particularly vulnerable situation inter alia due to intoxication or other drug influence is only one of many possible ways that this might be addressed.

However, it seems that the legislative amendments necessary to clarify consent and make it workable in cases of voluntary intoxication must in any case offer some actual legislative guidance when assessing what the effect of the complainant's level of intoxication is on her capability to consent. A legal presumption that would merely refer to the complainant being 'too affected by alcohol or drugs to give free agreement', as was suggested in Setting the Boundaries (Home Office, 2000, Recommendation 6 and para 2.10.9) seems to add little to the general definition of consent (Cowan, 2011, p. 162). Instead, the law should provide for a yardstick against which the physical effects of severe intoxication can be measured and on that basis, the complainant's capacity to consent can be assessed. This could be done by introducing a legal presumption along the lines of what Cowan suggests, where consent is considered not to be present if the complainant has lost certain physical capabilities. This could also be done by using the yardstick, applied in the Nordic countries, of the complainant's physical state becoming so weakened that she has lost the ability to resist sexual advances or that she is in a helpless or vulnerable state that is exploited by the defendant. These yardsticks can be transformed into legal presumptions as Sweden has done.

\section{Conclusion}

While the limitations of consent-based offences of rape in general, and the general definition of consent in the SOA 2003 in particular, might be regarded as primarily due to the English courts' narrow interpretation of consent, legal clarification seems to be necessary at this point if a departure is to be made for the narrow and somewhat unclear interpretation of consent in cases of voluntary intoxication in English law. While the position of the English courts and the English government seems to be that the law cannot clarify the situation by setting out a test for assessing when an intoxicated person loses the capacity to consent, my conclusion is that the law can and should be clarified to better accommodate these cases. Whereas the evidence regarding a person's state of drunkenness pri- 
marily pertains to the physical effects of intoxication, my argument is that the general definition of consent should be accompanied by a yardstick that focuses on these physical effects. This would make for a clearer and more workable offence when it comes to assessing the effects of intoxication on a complainant's capacity to consent. Admittedly, all types of offences rely on the courts' application and can thus be broadened or narrowed down through judicial interpretation. However, clarifying the law and providing the courts, defendants, complainants and the general public with a clearer direction as to where the boundaries between rape and consensual sexual behaviour lie, as was the aim of the SOA 2003, must be regarded as a step in the right direction. In contrast to England the Nordic countries have all up until recently adhered to a coercion-based model. Although Iceland and Sweden have both recently introduced consent-based definitions of rape both countries have, nonetheless, adhered to yardsticks that focus on the physical effects of intoxication rather than the capacity to consent in cases of voluntary intoxication. While Sweden has placed this yardstick under the umbrella of consent (voluntariness), Iceland has seemingly rejected the concept of consent as the base of the offence of rape in cases of voluntary intoxication. It remains to be seen whether these legislative amendments will lead to similar or different conclusions in practice.

\section{Bibliography}

Alpingi. (148. löggjafarping 2017-2018). Frumvarp til laga um breytingu á almennum hegningarlögum, nr. 19/1940, með síðari breytingum (kynferðisbrot). bingskjal 10-10. mál 8. Available from http://www.althingi.is/altext/pdf/148/s/0010.pdf

Ashworth, A. (2007). Rape: Consent - Intoxication. Criminal Law Review 900, 903.

Brå. (Rapport 2020:6). Den nya samtyckeslagen i praktiken. En uppföljning av 2018 års förändringar av lagreglerna rörande våldtäkt. Available from https://bra.se/download/18.7d27ebd 916ea64de5306522c/1591884069552/2020_6_Den_nya_samtyckeslagen_i_praktiken.pdf

Burman, M. (2011). Rethinking rape law in Sweden: Coercion, consent or non-voluntariness? In C. McGlynn \& V.E. Munro (Eds.), Rethinking Rape Law: International and Comparative Perspectives (pp. 196-208). London: Routledge

Cowan, S. (2011). All change or business as usual? Reforming the law of rape in Scotland. In C McGlynn \& VE Munro (Eds.), Rethinking Rape Law: International and Comparative Perspectives (pp. 154-169). London: Routledge.

Cowan, S. (2008). The Trouble with Drink: Intoxication, (In) Capacity and the Evaporation of Consent to Sex. Akron Law Review 41(4), 899-922.

Ferzan, K.K. and Westen, P. (2017). How to Think (Like a Lawyer) About Rape. Criminal Law and Philosophy 11(4), 759-800. https://doi.org/10.1007/s11572-016-9404-7

Finch, E. and Munro, V. (2007). The Demon Drink and The Demonised Woman: Socio-Sexual Stereotypes and Responsibility Attribution in Rape Trials Involving Intoxicants. Social and Legal Studies 16(4), 591-614. https://doi.org/10.1177/0964663907082737 
Elvin, J. (2008). The Concept of Consent under the Sexual Offences Act 2003. The Journal of Criminal Law 72(6), 519, pp. 519-536. https://doi.org/10.1350/jcla.2008.72.6.536

Home Office. (2000-I). Setting the Boundaries: Reforming the Law on Sex Offences.

Home Office. (Cm 5668, 2002). Protecting the Public: Strengthening protection against sex offenders and reforming the law on sexual offences.

Judicial College. (July 2019). The Crown Court Compendium: Part I: Jury and Trial Management and Summing Up 20-20 - 20-23.

Available from https://www.judiciary.uk/wp-content/uploads/2016/06/Crown-Court-Compen dium-Part-I-July-2019-amended-1-August-2019.pdf

Justis- og beredskapsdepartementet. Handlingsplan mot voldtekt 2019-2022. Available from https://www.regjeringen.no/contentassets/1469f9bedad1476aadb0369ee899ab65/handlingsp lan-mot-voldtekt-20192022.pdf

Justitsministeriet. (2020). Straffelovrådets betænkning om en frivillighedsbaseret voldtægtsbestemmelse (Betænkning nr. 1574). Available from https://www.justitsministeriet.dk/sites/ default/files/media/Pressemeddelelser/pdf/2020/betaenkning_1574_final.pdf

Munro, V. (2011). From consent to coercion: Evaluating international and domestic frameworks for the criminalization of rape. In C McGlynn \& VE Munro (Eds.), Rethinking Rape Law: International and Comparative Perspectives (pp. 17-29). London: Routledge.

Office for Criminal Justice Reform. (2016). Convicting Rapists and Protecting Victims - Justice for Victims of Rape, A Consultation Paper.

Regeringens proposition. (Prop. 2017/18:177). En ny sexualbrottslagstiftning byggd på frivillighet. Available from https://www.regeringen.se/4950e9/contentassets/20977a5e47ab41bd89 e4ff609208bfa8/en-ny-sexualbrottslagstiftning-byggd-pa-frivillighet-prop.-201718177

Vestergaard, J. (2019). Voldtægtsbestemmelse med frivillighed som forankringspunkt. Ugeskrift for Retsvæsen, Den litterære Afdeling, 277-286.

Wallerstein, S. (2009). 'A drunken consent is still consent'-or Is It? A Critical Analysis of the Law on a Drunken Consent to Sex Following Bree. The Journal of Criminal Law 73(4), 318344. https://doi.org/10.1350/jcla.2009.73.4.582

Simpson, B. (2016). Why has the Concept of Consent Proven So Difficult to Clarify? The Journal of Criminal Law 80(2), 97-123. https://doi.org/10.1177/0022018316639104

Sjölin, C. (2015). Ten years on: Consent under the Sexual Offences Act 2003. The Journal of Criminal Law 79(1) 20-35. https://doi.org/10.1177/0022018314566744

Statens offentliga utredningar. (SOU 2016:60). Ett starkare skydd för den sexuella integriteten. Available from http://www.regeringen.se/contentassets/8216d40ecc814613bccb394b4b1dfa 38/ett-starkare-skydd-for-den-sexuella-integriteten-sou-2016-60.pdf

Tadros, V. (2006). Rape Without Consent. Oxford Journal of Legal Studies 26(3), 515-543. https://doi.org/10.1093/ojls/gq1016

Temkin, J. and Ashworth, A. (2004). The Sexual Offences Act 2003: (1) Rape, sexual assaults and the problems of consent. Criminal Law Review, 328-346.

Cases

$R v$ Olugboja [1982] QB 320

$R v$ Gardner [2005] EWCA Crim 1399

$R v$ Bree [2007] EWCA Crim 804 
$R v$ Hysa [2007] EWCA Crim 2056

$R v$ Kamki [2013] EWCA Crim 2335

$R v$ Seedy Tambedou [2014] EWCA Crim 954

Iceland's Supreme Court Judgement no. 644/2015. Available from https:/www.haestirettur.is/ default.aspx?pageid=347c3bb1-8926-11e5-80c6-005056bc6a40\&id=14990613-16eb-40478dc0-13daeffc223e

Iceland's Supreme Court Judgement no. 252/2016. Available from https:/www.haestirettur.is/ default.aspx?pageid=347c3bb1-8926-11e5-80c6-005056bc6a40\&id=4389d91c-ba51-4976be95-b235df604d59

\section{Legislation}

Almenn hegningarlög no. 19/1940.

Brottsbalken no. 1962:700.

Lov om straff LOV-2005-05-20-28.

Rikoslaki no. 39/1889.

Straffeloven no. 1156/2018.

Sexual Offences Act (England) 2003. 